\title{
COMENTARIOS BIBLIOGRÁFICOS
}

El Origen de las Especies. Charles Darwin. 2008. Edición de Jaime Josa i Llorca. Traducción de Antonio Zulueta. Edición conmemorativa. Austral. Editorial Espasa Calpe, S.A. 695 pp.

Como expresa el editor, la presente edición reproduce la traducción al español que realizó Antonio de Zulueta en 1921 [Espasa-Calpe, 3 volúmenes] de la sexta edición (1872, John Murray, Londres) de la obra de Darwin.

La Introducción, del editor don Jaime Josa i Llorca, comprende siete tópicos (La teoría para la interpretación de la naturaleza, Darwin en Sudamérica, Darwin y Malthus, Charles Darwin y Alfred Russell Wallace, ¿La primera o la sexta edición de El origen de las especies?, El darwinismo en España y Darwin más de cien años después) y abarca 24 páginas.

En el texto, el traductor actualiza nombres científicos y/o adiciona notas explicativas. Antecediendo al Glosario intercala Adiciones y Correcciones a la sexta edición y en forma tabulada se consignan las principales adiciones y correcciones sucesivas hechas por el mismo Darwin a las ediciones de su obra.

En el Glosario preparado por W.S. Dallas por encargo de Darwin para la sexta edición inglesa, se añaden en esta traducción correcciones y actualizaciones en los nombres de los taxones usados por el colaborador de Darwin y notas aclaratorias para asegurar la comprensión del texto, como las correspondientes a Braquiópodos, Entomostráceos, efímeras, híbridos, Protozoos, etc.; sin embargo, no se precisa el alcance taxonómico del concepto roedores.

En esta edición se omiten los agradecimientos de Charles Darwin a W.S. Dallas y la razón de la necesidad de este glosario, que aparece en ediciones inglesas.

[William Sweetland Dallas (1824-1890), entomólogo y traductor inglés, fue quien también preparó el Índice de Variation on Domesticated Plants and Animals (1868) de Darwin].

Concluye con una bibliografía de 91 títulos sobre Historia de la Biología, Evolución e Historia de las Teorías Evolucionistas, Darwin y Darwinismo, y Darwinismo en España, con fechas de publicación (excluyendo los de Darwin) comprendidas entre 1931 y 1987; y un Índice Alfabético de 1.177 entradas.

Cabe destacar que en España las dos primeras traducciones de la obra de Darwin en comento pueden ser consideradas históricas: la del traductor Enrique Godínez (1877), de 573 páginas, que incluye la reproducción de cuatro cartas del gran naturalista, en las que le manifiesta su alegría por el avance de la traducción y por la claridad de la expresión, después de recibir los primeros pliegos con la petición de su consentimiento para la traducción, y que fue impresa en Madrid por el sello editorial de la "Biblioteca Perojo"; y la del genetista español Antonio de Zulueta y Escolano (1921), Espasa-Calpe, que ha sido la más difundida y publicada en los países en que se habla español.

Vicente Pérez D’Angello

Instituto de la Patagonia

Universidad de Magallanes. 
La Prensa Austral IMPRESOS.

Fono: 204012 / Fax: 247406 / Waldo Seguel 636

Punta Arenas - Chile 